\title{
Acceptance of bioeconomy principles in strategic documents on European and Slovak level
}

\author{
Lenka Navrátilová ${ }^{1}$, Blanka Giertliová ${ }^{1}{ }^{*}$, Iveta Hajdúchová $^{1}$, and Jaroslav Š́lka ${ }^{1}$ \\ ${ }^{1}$ Technical University in Zvolen, Faculty of Forestry, Department of Forest Economics and \\ Management, T. G. Masaryka 24, 96001 Zvolen, Slovakia
}

\begin{abstract}
.
Research background: The European Union has laid the foundations of European bioeconomy by publishing Innovating for Sustainable Growth: A Bioeconomy for Europe in 2012 and A sustainable bioeconomy for Europe: strengthening the connection between economy, society and the environment in 2018. These publications have inspired individual countries to develop their national bioeconomy strategy.

Purpose of the article: The lack of engagement in the area of bioeconomy appears to be a problem, as individual national strategies differ vastly amongst the countries. For successful bioeconomy development, there is a need to identify and address the differences in these strategies. That is why, we aim our attention at comparing European and Slovak bioeconomy legislative and at analysing to what extent have Slovak legislative implemented aspects of the European legislative.

Methods: The methodology of this study relies on document analysis of officially adopted policy strategies and roadmaps in the EU and Slovak Republic. The paper aims at defining the concept of bioeconomy, its relevance for the society and identifying the differences in European and Slovak strategic documents.

Findings \& Value added: Since Slovakia is a part of EU, it largely transmits the key areas of EU strategies to its own national strategy. Nevertheless, while comparing strategic documents on the two levels, disparities can be find resulting from specific prerequisites, economic situation and other circumstances. The main difference being the extend to what bioeconomy is addressed. While EU places a great importance to this concept, Slovakia does not aim as much attention to it.
\end{abstract}

Keywords: bioeconomy; bioeconomy strategies; strategic documents

JEL Classification: $Q 57 ; P 48 ; F 53$

\footnotetext{
* Corresponding author: blanka.giertliova@tuzvo.sk
} 


\section{Introduction}

From a global perspective, the bioeconomy is presented through (but not only) political strategies as a path to a new and more sustainable economy. At present, due to the current economic and environmental situation, the concept of bioeconomy is increasingly discussed in professional as well as lay circles. Bioeconomy as a concept is often perceived to be a way to tackle all the great challenges of today' s society [1]. When it comes to these societal challenges (climate change, land and ecosystem degradation, growing population, food security etc.) their impact is far-reaching. That's why, bioeconomy is a cross-sectoral approach encompassing all sectors relying on biological resources, which promotes the replacement of non-renewable natural resources by the renewable ones [1].

The EU is not the only region of the world where the concept of the bioeconomy has been pro-moted since the early 2000s. The term bioeconomy was probably first used at a meeting of the American Association for the Advancement of Science in 1997 [2]. As, from European perspective, the bioeconomy is presented as a central element for functioning and successful European economy, European Commission has published a bioeconomy strategy Innovating for sustainable growth: A bioeconomy for Europe in 2012. This strategy was created in the context of the need for radical change in production, consumption, processing, storage, recycling, and biological resources disposal as an answer to abovementioned global societal problems. The focus of the strategy is aimed at ensuring food security, sustainable management of natural resources, reducing dependence on nonrenewable resources, mitigating, and adapting to climate change, creating jobs and maintaining European competitiveness. Along with this strategy, an action plan was published presenting a list of 12 actions needed to achieve set goals. These actions come within the ambits of investments in research, innovation and skills; reinforced policy interaction and stakeholder engagement; enhancement of markets and competitiveness in bioeconomy [3].

Since 2018, an updated European strategy and action plan are in effect, entitled $A$ sustainable bioeconomy for Europe: strengthening the connection between economy, society, and the environment, which complements the original 2012 strategy. This strategy aims at developing a list of 14 actions launched by 2019 addressing the global societal challenges. The goals set by the former strategy are still found adequate, so they remain unaltered. The latter strategy, however, acknowledges that bioeconomy must be a part of circular economy. Therefore, in order to develop sustainable bioeconomy, it must comply with principles of circular bioeconomy [1]. As European policy agenda focuses on low carbon society, ecosystem resilience and circular economy, there are various sectoral strategies in place at the European level, that are relevant for the European bioeconomy policy regarding sectors such as energy, forestry, agriculture, fishery, pharmaceutical sector etc.

Although, the importance of bioeconomy has been acknowledged, and the example has been set by the European Commission, not all European countries have developed their own national bioeconomy strategies. So far, 15 European countries have developed explicit bioeconomy strategies, e.g. Austria, Germany, Belgium, Norway etc. [4]. Admitting, between these national strategies considerable differences can be found nevertheless there are also similarities, such as focus on economic output, public welfare, cross-sectoral approach and efforts for climate change mitigation [5]. There are also countries that published bioeconomy-related strategies in the areas important for bioeconomy, such as forestry, agriculture, energy etc [6]. It is necessary for individual countries to contribute to the European and global efforts for the transition towards bioeconomy, as it is fight that can only succeed if we cooperate. 
To this date, there is no explicit bioeconomy strategy published in Slovakia on national level. It is necessary for Slovakia to focus on developing the national bioeconomy, as it can help solve not just the global societal challenges, but it can also increase competitiveness, economic growth and welfare of the country. However, implementation of bioeconomy carries not only opportunities, but risks as well, such as lower food security, soil destruction, stress on freshwater supplies etc. All opportunities and risks must be taken into account in development of bioeconomy in Slovakia. There is no clear way of implementing the bioeconomy strategy, as bioeconomy is a part of broader policy focused on green growth, new industrial and agriculture policy and a fossil fuels-independent society [7].

Until 2019, Slovakia was one of the countries that govern national bioeconomy through several bioeconomy-related strategies in various sectors. In the beginning of 2020, a strategy has been published that is addressing several bioeconomy-related topics, yet the term bioeconomy is still underused in this strategy. Low-Carbon Development Strategy of the Slovak Republic until 2030 with a View to 2050 was published by the Ministry of the Environment of Slovak Republic with the ambition to ensure climate neutrality in Slovakia by 2050 . This strategy acknowledges the role of forests in achieving the set goal, as their sequestration services are essential for ensuring climate neutrality. In Slovakia forest land covers approx. $40 \%$ of the total area and forestry itself has a long tradition. Therefore, forestry in Slovakia has the potential to grow and produce high value added [8], to this date value added in Slovak forestry represents $15,8 \%$ of EU [9]. For successful bioeconomy development, there is a need to identify and address the differences in bioeconomy-related strategies. That is why, we aim our attention at comparing European and Slovak bioeconomy legislative and at analysing to what extent have Slovak legislative implemented aspects of the European legislative.

\section{Materials and methods}

As the basic method document analysis, as a form of qualitative research, was used. The two analysed strategic documents were selected as the main documents governing bioeconomy on European (A sustainable bioeconomy for Europe: strengthening the connection between economy, society and the environment) and Slovak national level (Low-Carbon Development Strategy of the Slovak Republic until 2030 with a View to 2050).

A document review approach aiming to assess the interlinkages and coherence for policy implementation was used and modified. Regarding the document analysis itself, it was conducted based on selected pair of criteria, which are following:

- Main goals of the document

- Actions suggested for achieving the set goals

Subsequently, the documents were analyzed using keywords, which were carefully determined according to the main aspects of bioeconomy as follows:

- Biomass

- Climate/climate change

- Sustainability/sustainable management

- Bioeconomy

- Circular economy

- Green economy 


\section{Results}

Results of the conducted analyses regarding set goals and suggested actions for achieving these goals are shown in the Table 1, whereas Table 2 presents results of the key words analyses.

Table 1. Goals and actions presented in documents

\begin{tabular}{|c|c|c|}
\hline & $\begin{array}{l}\text { Low-Carbon Development } \\
\text { Strategy of the Slovak Republic } \\
\text { until } 2030 \text { with a View to } 2050\end{array}$ & $\begin{array}{l}\text { A sustainable bioeconomy for } \\
\text { Europe: strengthening the } \\
\text { connection between economy, } \\
\text { society and the environment }\end{array}$ \\
\hline Goals & $\begin{array}{l}\text { identification of measures, } \\
\text { including additional measures, } \\
\text { to achieve climate neutrality in } \\
\text { Slovakia by } 2050\end{array}$ & $\begin{array}{l}\text { - ensuring food and nutrition } \\
\text { security } \\
\text { - managing natural resources } \\
\text { sustainably } \\
\text { - reducing dependence on non- } \\
\text { renewable, unsustainable } \\
\text { resources whether sourced } \\
\text { domestically or from abroad } \\
\text { - mitigating and adapting to } \\
\text { climate change } \\
\text { - strengthening European } \\
\text { competitiveness and creating } \\
\text { jobs }\end{array}$ \\
\hline Actions & $\begin{array}{l}\text { - overall emission reductions } \\
\text { and enhancement of removals } \\
\text { up to } 2050 \\
\text { - producing energy from } \\
\text { renewable source } \\
\text { - increasing energy efficiency }\end{array}$ & $\begin{array}{l}\text { - strengthen and scale-up the } \\
\text { bio-based sectors, unlock } \\
\text { investments and markets } \\
\text { - deploy local bioeconomies } \\
\text { rapidly across Europe } \\
\text { - understand the ecological } \\
\text { boundaries of the bioeconomy }\end{array}$ \\
\hline
\end{tabular}


Table 2. Key words analysis

\begin{tabular}{|c|c|c|}
\hline Key words & $\begin{array}{l}\text { Low-Carbon Development Strategy } \\
\text { of the Slovak Republic } \\
\text { until } 2030 \text { with a View to } 2050\end{array}$ & $\begin{array}{l}\text { A sustainable bioeconomy for } \\
\text { Europe: strengthening the } \\
\text { connection between economy, } \\
\text { society and the environment }\end{array}$ \\
\hline Biomass & $\begin{array}{l}\text { - } \text { natural renewable resource with the } \\
\text { biggest energetic potential } \\
\text { - } \text { helps increase the energetic self- } \\
\text { sufficiency of Slovakia } \\
\text { - } \text { helps decrease the GHG emissions } \\
- \text { reduction of improper combustion } \\
- \text { restriction of the use of biomass } \\
\text { from unsustainable sources } \\
- \text { acknowledging the role of biomass } \\
\text { in storing CO2 }\end{array}$ & 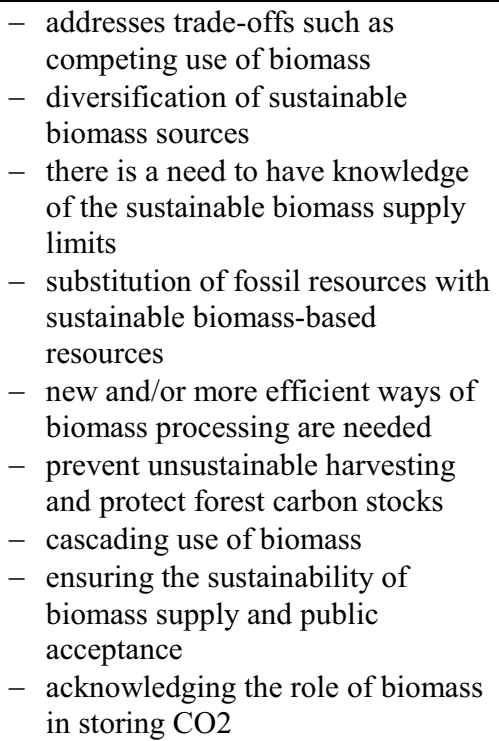 \\
\hline $\begin{array}{l}\text { Climate/climate } \\
\text { change }\end{array}$ & $\begin{array}{l}\text { - } \text { acknowledging the huge destructive } \\
\text { potential of climate change } \\
\text { - } \text { increase the preparedness of Slovak } \\
\text { republic to climate change effects } \\
\text { - } \text { increasing energy efficiency in } \\
\text { industry } \\
\text { - } \text { mitigation of negative effects of } \\
\text { climate change on ecosystems } \\
- \text { decreasing the GHG emissions } \\
\text { while enlarging carbon sinks }\end{array}$ & $\begin{array}{l}\text { - acknowledging climate change } \\
\text { - adaptation and mitigation of } \\
\text { climate change through "negative } \\
\text { emissions" and carbon sinks } \\
\text { - enhancing the capacity of } \\
\text { ecosystems to regulate climate } \\
\text { - increase the contribution of the } \\
\text { bioeconomy to climate change } \\
\text { mitigation and renewable transition }\end{array}$ \\
\hline $\begin{array}{l}\text { Sustainability/ } \\
\text { sustainable } \\
\text { management }\end{array}$ & $\begin{array}{l}\text { - } \text { large potential to reduce GHG } \\
\text { emissions } \\
\text { - } \text { promoting sustainable mobility } \\
\text { - } \text { sustainable forest management } \\
\text { - } \text { promoting innovation and research } \\
\text { for sustainable technology } \\
\text { - } \\
\text { sustainable use of natural } \\
\text { renewable resources }\end{array}$ & $\begin{array}{l}\text { - } \text { great importance of sustainability } \\
\text { emphasised many times throughout } \\
\text { the document } \\
\text { - } \\
\text { sustainable forest management } \\
\text { - } \text { promoting sustainable food and } \\
\text { farming systems, forestry and bio- } \\
\text { based production } \\
\text { - } \\
\text { sustainability is an opportunity for } \\
\text { all parts of Europe } \\
\text { - } \\
\text { sustainability will contribute to } \\
\text { achieving land degradation } \\
\text { neutrality } \\
\text { - } \text { sustainable use of natural } \\
\text { renewable resources } \\
\text { - } \text { sustainable development creates } \\
\text { new business opportunities. }\end{array}$ \\
\hline
\end{tabular}


Table 2 continuation

\begin{tabular}{|c|c|c|}
\hline Key words & $\begin{array}{l}\text { Low-Carbon Development Strategy } \\
\text { of the Slovak Republic } \\
\text { until } 2030 \text { with a View to } 2050\end{array}$ & $\begin{array}{l}\text { A sustainable bioeconomy for } \\
\text { Europe: strengthening the } \\
\text { connection between economy, } \\
\text { society and the environment }\end{array}$ \\
\hline Bioeconomy & $\begin{array}{l}\text { - does not provide a definition } \\
\text { - increased promotion of bioeconomy }\end{array}$ & $\begin{array}{l}\text { - } \text { provides a definition } \\
\text { - deploy local bioeconomies rapidly } \\
\text { across Europe } \\
\text { - } \text { bioeconomy has the potential for } \\
\text { rural, coastal, and urban areas } \\
\text { development } \\
\text { - } \text { support inclusive bioeconomies in } \\
\text { rural areas }\end{array}$ \\
\hline $\begin{array}{l}\text { Circular } \\
\text { economy }\end{array}$ & $\begin{array}{l}\text { - } \text { circularity is important in achieving } \\
\text { climate neutrality } \\
\text { - implementation of circular } \\
\text { economy principles }\end{array}$ & $\begin{array}{l}\text { - bioeconomy should be sustainable } \\
\text { and circular to be successful } \\
\text { - circular urban development plans } \\
\text { could translate into very significant } \\
\text { economic and environmental gains. } \\
\text { - } \text { speed up the deployment of circular } \\
\text { economy models }\end{array}$ \\
\hline Green economy & $\begin{array}{l}\text { - green jobs } \\
\text { - green investment } \\
\text { - green public procurement } \\
\text { - building green infrastructure }\end{array}$ & $\begin{array}{l}\text { - } \text { creation of greener, more cost- } \\
\text { effective industrial processes } \\
- \text { green public procurement } \\
- \text { green jobs } \\
- \text { green chemicals } \\
- \text { green infrastructure }\end{array}$ \\
\hline
\end{tabular}

Low-Carbon Development Strategy of the Slovak Republic until 2030 with a View to 2050, as bioeconomy itself, has a cross-sectoral character. The strategy tackles challenges across numerous sectors - energy sector, industrial processes sector, transport sector, agriculture, land use, land use change and forestry sector (LULUCF) and waste sector. Measures are presented for individual sectors to achieve the goal of the strategy climate neutrality. The strategy acknowledges the huge destructive potential of climate change and emphasises the need for Slovakia to be prepared for its negative effects, as well as the need to mitigate the negative effects on the ecosystems. Forest ecosystems play an important role in achieving the climate neutrality, as they help to reduce GHG emissions, increase the energetic self-sufficiency of Slovakia and they produce forest biomass, which is seen as natural renewable resource with the biggest energetic potential.

The strategy further promotes sustainable mobility, forest management, use of natural resources and innovation and research for sustainable technology, as sustainability is seen as very potential in reducing GHG emissions. Although, this strategy addresses very bioeconomy-relevant problems, the term bioeconomy is only used once throughout the document, as one of the additional measures for agriculture is "increased support for the bioeconomy". On the other hand, bioeconomy-related concepts -circular economy and green economy- are appearing more often in the document. Circularity is seen as very important in achieving the set goal; therefore, implementation of circular economy principles is essential. The attention is also aimed at green jobs, green investment, green public procurement, or green infrastructure.

A sustainable bioeconomy for Europe: strengthening the connection between economy, society and the environment aims to stimulate implementation of a sustainable European bioeconomy. The 2012 strategy was updated responding to changed European policy priorities, such as the renewed Industrial Policy Strategy, the Circular Economy Action Plan and the Communication on Accelerating Clean Energy Innovation, while all of 
these perceive circular bioeconomy to be important in achieving their set goals. The updated strategy proposes 14 concrete measures to achieve its goal. The strategy, as the former, acknowledges climate change and its negative effects, as well as the role of forest ecosystems in their mitigation. The attention is also aimed at enhancing the capacity of ecosystems to regulate climate, cascading use of biomass or ensuring the sustainability of biomass supply and public acceptance. The strategy further addresses trade-offs, such as competing use of biomass.

The strategy promotes sustainable forest management, food and farming systems or biobased production, as sustainability will contribute to achieving land degradation neutrality and it presents window of opportunities for the whole Europe. In contrast to the former strategy, the European Bioeconomy Strategy explains bioeconomy itself, as well as to how does bioeconomy contribute to European priorities. According to this strategy, bioeconomy has the potential for rural, coastal, and urban areas development and for that reason it is necessary to deploy local bioeconomies rapidly across Europe and support inclusive bioeconomies in rural areas. Bioeconomy itself could not be successful, that is why for bioeconomy to succeed it needs to have sustainable and circular principles at heart. Circular urban development plans could translate into very significant, not only, environmental, but also economic gains. The attention is also paid to creation of greener, more cost-effective industrial processes, as well as green public procurement, green jobs, green chemicals and green infrastructure.

\section{Discussion}

European Commission has introduced new initiatives based on the environmental challenges and political developments at the European level that resulted in publishing of strategic documents, such as European Green Deal, European Bioeconomy Strategy etc. It is appropriate for Slovakia to set up horizontal cross-sectoral coordination involving the political level as soon as possible, as a response to these initiatives. Based on previous research [10 - 12], the application of the bioeconomy concept in the conditions of the Slovak Republic has suitable preconditions as well as the potential for future development. The Low-Carbon Development Strategy is the first step of such efforts. In accordance with the recommendations of [13] a supportive political framework, close cooperation between countries and free exchange of information should be the ultimate goal towards furthering the progress of a future bioeconomy. For that reason, it is proposed to create a coordinating and consultative advisory body to the Government of the Slovak Republic entitled the Council of the Government of the Slovak Republic for the European Green Deal and LowCarbon Transformation.

The Low-Carbon Development Strategy is in line with European documents, as the Paris Agreement, European Green Deal, A Clean Planet for all, European Bioeconomy Strategy etc, which means that Slovakia respects and implements European regulation into national legislative. The publishing of the Low-Carbon Development Strategy itself together with the proposed coordinating body is a sign that low-carbon transformation in Slovakia is taken seriously. Nevertheless, the economic opportunities resulting from bioeconomy are being either neglected or not seen at all, while in the European Bioeconomy Strategy, these are very well acknowledged. Which may be explaining why the bioeconomy development in Slovakia is being slow.

Also, biomass in Slovakia, according to the Low-Carbon Development Strategy, is mostly seen as a renewable natural resource, utilization of which can help reduce GHG emissions. Woody biomass processing seems to be also the most promising renewable energy generation portfolios for revitalizing rural regional economies, especially in areas where alternative opportunities are limited $[14,15]$. European Bioeconomy Strategy in the 
context of biomass also addresses trade-offs [16], diversification of biomass utilization and new innovative ways of biomass processing. Further, great importance of sustainability is emphasised many times throughout the EU document, as sustainability is seen as an opportunity for the whole Europe. In Slovakia, the importance of sustainability is not emphasised as much as it is in the European Bioeconomy Strategy. Finally, the biggest difference between the two analysed documents is the lack of the term bioeconomy in The Low-Carbon Development Strategy, while the European Bioeconomy Strategy is based on the concept itself.

This work was supported by the Slovak Research and Development Agency under the Contract no. APVV-18-0520 and by the Scientific Grant Agency of the Slovak Republic under the grant VEGA $1 / 0655 / 20$.

\section{References}

1. EC (2018) A sustainable bioeconomy for Europe: strengthening the connection between economy, society and the environment. Updated Bioeconomy Strategy. Luxembourg: Publications Office of the European Union.

2. Birner, R. (2018). Bioeconomy Concepts. In: Bioeconomy. Shaping the Transition to a Sustainable, Biobased Economy, 1st ed.; Lewandowski, I. (Eds.), Springer: Cham.

3. EC (2012) Bioeconomy Strategy, "Innovating for Sustainable Growth: A Bioeconomy for Europe”, COM (2012) 60 Final, Brussels. Luxembourg: Publications Office of the European Union.

4. Dietz, T., Börner, J., Förster, J.J., Von Braun, J. (2018). Governance of the bioeconomy: A global comparative study of national bioeconomy strategies. Sustainability, 10(9), 3190.

5. McCormick, K.; Kautto, N. (2013) The Bioeconomy in Europe: An Overview. Sustainability, 5(6), 2589-2608.

6. Böcher, M., Töller, A. E., Perbandt, D., Beer, K., Vogelpohl, T. (2020). Research trends: Bioeconomy politics and governance. Forest Policy and Economics, 118, 102219.

7. Kircher, M. (2019). Bioeconomy: Markets, Implications, and Investment Opportunities. Economies 2019, 7(3), 73.

8. Potkány, M., Gejdoš, M., Debnár, M. (2018). Sustainable innovation approach for wood quality evaluation in green business. Sustainability, 10(9), 2984

9. The World Bank (2019). Agriculture, forestry, and fishing, value added (\% of GDP) Slovak Republic. The World Bank.

https://data.worldbank.org/indicator/NV.AGR.TOTL.ZS? contextual=region\&locations $=$ SK\&name_desc $=$ true

10. Navrátilová, L., Výbošt’ok, J., Dobšinská, Z., Šálka, J., Pichlerová, M., Pichler, V. (2020). Assessing the potential of bioeconomy in Slovakia based on public perception of renewable materials in contrast to non- renewable materials. AMBIO A Journal of the Human Environment, 49(12), 1912-1924.

11. Liobikiene, G., Chen, X., Streimikiene, D., Balezentis, T. (2020). The trends in bioeconomy development in the European Union: Exploiting capacity and productivity measures based on the land footprint approach. Land Use Policy, 91, 104375. 
12. Parobek, J., Paluš, H., Moravčík, M., Kovalčík, M., Dzian, M., Murgaš, V., ŠimoSvrček, S. (2019). Changes in carbon balance of harvested wood products resulting from different wood utilization scenarios. Forests, 10 (7), 590.

13. Issa, I., Delbrueck, S., Hamm, U. (2019). Bioeconomy from experts' perspectives Results of a global expert survey. PLOS ONE 2019, 14 (5), e0215917.

14. Jackson, R., Neto, A.B.F., Erfanian, E., Járosi, P. (2019). Woody Biomass Processing and Rural Regional Development. Economic Development Quarterly, 33(3), 234-247.

15. Favero, A., Mendelsohn, R. (2014). Using markets for woody biomass energy to sequester carbon in forests. Journal of the Association of Environmental and Resource Economists, 1(1-2), 75-95.

16. Halaj, D.; Brodrechtová, Y. (2018). Marketing decision making in the forest biomass market: the case of Austria, Finland and Slovakia. Forest policy and economics, 97. 201-209. 